\title{
ZONGULDAK VE GEVRESINNDE MÜDAFAA-İ HUKUK ÇALIŞMALARI
}

\author{
Doç, Dr. Ali SARIKOYUNCU
}

\author{
GİRIŞ :
}

\section{Mücadele Fikrinin Doğuşu}

Kömür rezervlerinin işletilmeye açılması sebebiyle özellikle 1882 yılından itibaren yöreye yerli yabancı göçler olmuştur. Bu göçler sonucu, yöre nüfusu hızla artmıştır. Bunun en belirgin örneği, 1899 öncesinde Erẹ̆gli'nin Elvan köyünün bir mahallesi iken bu gün il merkezi olan Zonguldak'ın ortaya çıkışıdır ${ }^{1}$. Bu göçler esnasında maden işletmecisi olarak Rumlar, Ermeniler, Fransız ve İtalyanlar da yöreye gelmişlerdi².

Milli Mücadele başlarında Zonguldak şehir merkezinde yabanc1lar ve azınlıklar hakim duruma geçmişti. Bolu Mebusu Tunalı Hilmi Bey; "Zonguldak'ta Askerlik Mükellefiyeti Hakkında Kanun” teklifi ${ }^{3}$ ile ilgili olarak TBMM'nin 21.10.1920 tarihli oturumunda yaptığ konuşmasında bu durumu şöyle açıklamaktaydı:

"Efendim intibahat (Seçimler) vesilesiyle oralara gittim. Bundan 8-10 yıl evvelde Karadeniz Ereğlisi'nde Kaymakamdım. Oradan ayrılırken 450 haneden ibaret bıraktığım Zonguldak'1 1500 haneyi tecavüz bir sürette meskun buldum. Halbuki evvelce benim hatıralarima göre orada 100, 150 kadar hatta 200 kadar müslüman evi vardı. $\mathrm{Bu}$ sefer Beyler, maatteessüf 50 kadar bile müslüman evi bulamadım. 1500 'ü mütecaviz ecnebiden Rum ve Ermeni'den mürekkep haneyle meskun olduğunu gördüm"4.

Ahmet Naim de Zonguldak kömür havzasındaki nüfus durumunu şöyle açıklamaktadır: “. . . Hatta Havza'da Fransız, İtalyan kolonileri

1 Zonguldak'ın 1916 yılında nüfusu 30563'e yükselmiştir. (Müstakil Bclu Sancağı Sal. name-iResmisi 1334 sene-i Hicriyesine Mahsus, Ahmet İhsan Matbaas1, İstanbul, s. 278).

2 Karadeniz Bölge Komutanlığı ve Ereğli Garnizonu El Kitabl, Basım yeri (Yok) 1984, s.11.

3 Bu kanun teklifi kanunlaşmamıştır.

4 TBMM Zabit Ceridesi, C. 5. s.122. 
gibi bir de Pontus kolonisi türemişti"'5. Zonguldak'ın o günlerdeki durumunu Tahir Karauğuz da şöyle belirtmektedir: "Şu veya bu rengi taşıan devletler, Şanghay'da olduğu gibi Havza'da yer yer nüfuz mintıkaları, koloniler kurmuşlardır. Bu yetmiyormuş gibi o ana kadar bağrımızda barındırdığımız ekalliyet unsurlarının bile nüfuz mıntıkaları tebarüz etmişti"'6. Çünkü azınlıklar yörenin sadece kömür madeni işletmeciliğine el atmakla kalmamışlar aynı zamanda ticaretini de ellerine geçirmişlerdi. Hatta 30 Temmuz 1919'da kurulan Zonguldak Ticaret ve Sanayi Odası yönetim kurulu da azınlıklardan oluşmaktayd1 ${ }^{7}$.

Yine Milli Mücadele başlarında İttihat ve Terakki Fırkası kendisini fes etmişti. Onun yerini almak için kurulan Teceddüt Fırkası aktif bir rol oynayamiyordu. Bununla birlikte memleketin en güzide gücünü İttihatçılar oluşturuyordu. Ancak Itttihatçıların baskısından kurtulan muhalefet, 1919 yılı Ocak ayında Hürriyet ve İtilaf Fırkası'nı yeniden kurmuşlardı8.

Memleketin ileri gelen asker ve sivil yöneticileri ile eşraf bu iki parti arasında bölünmüştü. Ülkenin bir köşesi olan Zonguldak ve havalisinde de durum aynıydı. Cü̈nkü o tarihlerde yöre bağımsız Bolu Sancağı'nın idaresi altında bulunuyordu. Sancağın başında ise Mutasarrıf Ali Haydar Bey vardi.

Ali Haydar Bey'in ise, bu tarihlerde Hürriyet ve Itilaf Firkasi ile ilişki içinde bulunması muhtemeldir. Zira 4 Mart 1919'da idareyi ele alan Damat Ferit Hükümeti'nin Ali Haydar Bey'i görevden almadığına bakılırsa, Bolu'daki Hürriyet ve Ittilaf Fırkası'nın ileri gelen-

5 Ahmet, Naim, Zonguldak Havzast Uzun Mehmet'ten Bugüne Kadar, İstanbul, 1934, s. 71.

621 Haziran, Zonguldak'ın Milli Idareye Kavuştığu Günün 15 ıci Yildönümü, Zonguldak Halkevi yayını, Karaelmas Basımevi 1937, s. 8.

7 Yönetim Kurulu; Madenci Maksut Bey (Başkan), Tüccar Bartınlı Kosmitis Efendi 2. (Bașkan), Madenci Mihal Hristo Filis, Tüccar İstanbulluyan Karabet Efenci, Madenci Hoca İstefan Efendi, Tüccar Tomo Fodyadis Efendi, Tüccar Ohanis Hazerbetyan Efendi, Tüccar Bekir Sıtkı Bey ve Tüccar Hacı Antranik Efendi'dir. Cumhuriyetin On $r_{l}$ lında Zonguldak ve Maden Kömürü Havzası, İstanbul 1933, s. 49.

8 Tarık, Z. Tunaya, Türkiye'de Siyasi Partiler, Istanbul 1952 s. 447 vd.

9 Ḣaydar Bey (Ali Haydar Yuluğ) 1878'de İmir'de doğmuştur. 1902'de Mektebi Mülkiye'yi bitirdikten sonra çeşitli ilçelerde kaymakamlık kısa bir süre mebusluk daha sonra mülkiye müfettişliği yaptı. 1916-yılında mutasarrıflığa yükseltildi. Sırasıyla; Antep, Urfa, Aydın, Isparta, Çatalca mutasarriflıklarında bulunduktan sonra 23 Ocak 1919 tarihinde Bolu Mutasarnflı̆ı'na atand. (Ali C̣ankaya, Yeni Mülkiye Tarihi ve Mülkiyeliler, C. III, Ankara 1969, s. 939). 
lerin mutasarrıftan bir yakınmaları olmadığı sonucuna varmak mümkündür.

Gerçekten Bolu Livası yöneticisiyle eşrafiyla Anadolu'da başlamı̧ olan Milli Mücadele çabalarına karşı kayıtsız durmaktaydı. Sivas Kongresine delege göndermediği gibi Kongre kararlarını uymaya isteksiz görünüyordu. Nitekim 12 Eylül 1919 tarihinde alınan İstanbul ile haberleşmesinin kesilmesi kararına da uymamıştı ${ }^{10}$.

Ayrıca başta Bartın Kaymakamı Durmuş Bey olmak üzere ilçe yöneticileri de İstanbul Hükümeti taraftarı bir politika izliyorlardı11.

Diğer taraftan Hürriyet ve İtilâf Fırkası Damat Ferit'in iktidara gelmesiyle menfi propagandalarını daha da arturmışt. Teceddüt Firkası proğramının bir maddesine kadınların toplantılara katılabileceklerini de koymuştu. İşte, Bolu Hürriyet ve İtilâf Fırkası yöneticileri, Teceddüt Fırkası'nın bu maddesini ele alarak "Kadınların kocalarının müsadesi olmadıkça sokağa çıkmalarına şeriatın müsadesi yoktur. Teceddütçüler, şeriatı dahi ayak altına alıyorlar"12 diye propagandaya başlamışlardı. Hatta bu menfi düşüncelerini çıkardıkları Kürsi-i Millet adlı gazete vasitasılyla yörenin köylerine kadar yayıyorlardı. Bu gazetenin Milli Mücadele aleyhindeki bu yazıları; İstanbul'da Refi Cevat'n çıkardığı Alemdar ${ }^{13}$ gazetesiyle de destekleniyordu ${ }^{14}$. Ayrıca Kastamonu'da çıkan Zafer gazetesi de menfi fikirleri ile Zonguldak ve havalisi üzerinde etkili oluyordu ${ }^{15}$.

Hürriyet ve Ittilâf Fırkası'nın çalışmalarının da etkisiyle, Bartın, Devrek, Zonguldak ve Ereğli halkının bir kısmı mütereddit büyük bir çoğunluğu ise, İstanbul taraftarı olmuşlardı16. Tabiî yöre halkının bu durumá gelmesinde İtilâf devletleri de etkili olmuştu. Zira, daha

10 Kamil Erdeha, "Milli Mücadelede Livalar ve Mutasarrfflar" Mülkiyeliler Birligi Dergisi, S. 45 (1976) s. 38.

11 Bu konuda bkż., Ali Sarıkoyuncu, Milli Mücadele'de Zonguldak ve Havalisi Ankara

Ưniversitesi Türk Inkılâp Tarihi Enstitüsü yayınlanmamıș doktora tezi, Ankara 1990 s. $175-180$.

12 Rahmi Apak, Istiklal Savaşında Garp Cephesi Nasıl Kuruldu, Güven Matbaası, İstanbul 1942, s. 117.

$13 \mathrm{Bu}$ gazete, Hürriyet ve İtilaf Partisinin ülke genelindeki yayın organıdır.

14. R. Apak, a.g.e., s. 117-118.

15 Zafer gazetesi de Kastamonu ve havalisinde Hürriyet ve İtilaf Fırkası'nın etkili bir yayın organıydı (Nurettin Peker, 1918-1923 İstiklal Savaşı'nın Vesika ve Resimler Inönü Sakarya ve Dumlupınar Zaferini Sağlayan İnebolu ve Kastamonu Havalisi (ISSVR) Istanbul, 1955, s. 32).

16 N. Peker, $t S V R$, s. 194. 
8 Mart 1919 da Fransız askerleri Zonguldak'a ayak basmışlardı. Öte yandan iç kısımlarda kargaşalık çıkartmak üzere 7 Şubat 1919'da beş Ingiliz subayı Bolu'ya gönderilmişti. Bu subayların yanında azınlıkların taşkınlıklarını arttırmak üzere bir de papaz bulunuyordu17.

Bütün bunlara ilaveten ileride açıklanacağı üzere, İstanbul Hükümeti'nce Zonguldak Bağımsız Mutasarrıflık haline getirildi. Başına da Damat Ferit'in adamlarından Kadri Bey Mutasarrıf olarak tayin edildi ${ }^{18}$. Ayrıca, yöre gençleri Zonguldak kömür havzasında maden işçisi olarak çalışmaktaydılar. Ancak üzülerek belirtelim ki, bu gençlerin büyük bir çoğunluğu Fransız şirketi ile azınlıkların kömür ocaklarında çalı̧̧ıorlardı. Hatta başlarındaki çavuşların büyük çoğunluğu da Rum idi ${ }^{19}$.

Bütün bu belirtilen nedenlerden dolayı, Zonguldak ve havalisinde; Anadolu'nun diğer yörelerine göre Milli Mücadele fikrinin biraz daha geç ortaya çıktığını görüyoruz. Bu konuda örnek olarak, Denizli Sancağı'nı gösterebiliriz. Nitekim, Yunanlıların İzmir'e asker çıkardığını öğrenen ${ }^{20}$ Denizli Mutasarrıfı Faik Bey; Askerlik Şubesi Başkanı Tevfik Bey'i Müftü Ahmet Hulusi Efendi'yi, Belediye Başkanı Hacı Tevfik Bey'i ve eşraftan bazı kimseleri yanına çă̆ırarak hemen durumu görüşüp bir miting tertiplemeye karar vermişlerdi. 15 Mayıs 1919 'da yapılan mitingte de düşmana silahla karşı konulması kararlaştırılmışt ${ }^{21}$.

Görüldüğü üzere, Denizli'de yöneticilerle halk el ele vermişlerdir. Fakat yukarıda da belirttiğimiz gibi bu birlik ve beraberliği Milli Mücadele'nin ilk günlerinde Zonguldak ve havalisinde görmek mümkün olmamıştır. Ancak yörede Milli Mücadele fikrinin doğuşuşu gecikmedi. Denizli'de Müftü Ahmet Hulusi Efendi'nin Milli Mücadele için yaptığı önderliği ${ }^{22}$ burada da yine din adamları üstlenmişler-

17 R. Apak, a.g.e., s. 118.

18 Bu konuda bkz. A. Sarikoyuncu, agt s. 169-175.

(19) TBMM Zabit Ceridesi, C. 5, s. 125.

201415 Mayıs gecesi sabaha doğru Yunan askerleri İzmir rıhtımına ayak basmaya başladıkları an, İzmir Red-i Ilhak Heyeti ve Belediyesi yurdun her tarafına olduğu gibi Denizli’ye de Yunan işgalinin başladığını gösteren telgrafını göndermiști. Bu telgrafın tam metni için bkz. Türk tstiklal Harbi C. 2 1. s. 63.

21 Bu konuda daha geniş bilgi için bkz. , M. Akif Tütenk, Milli Mücadele'de Denizll, İzmir, 1949, s. 6 vd.,

22 Ahmet Hulusi Efendi’nin Milli Mücadele'deki hizmetleri hakkında kilgi için bkz. Ali Sarkkoyuncu "Milli Mücadele'de Denizli Müftüsü Ahmet Hulusi Efendi" Diyanet Dergisi C. 27, Sayı: 4 (Ekim, Kasım, Aralık 1991), s. -239-292. 
di. Cide Müftüsü Hüseyin Efendi'nin aksine ${ }^{23}$, bunlardan Beycuma Müderris'i-Hüseyin Efendi ile Zonguldak Müftüsü İbrahim Efendi24 yöre yerleşim yerlerini dolaşarak halkı Kuva-yı Milliye lehine kazanmak isterlerken, Bartın Müftüsü Rifat Efendi de bulunduğu yerde Milli Mücadele için faaliyette bulunuyordu25.

Dürri-zâde'nin fetvasına karşı Anadolu uleması tarafindan hazırlanan "Fetva-yı Şerife'yi de imzalayan Devrek kadısı ve Müftüsü Abdullah Sabri Efendi ise, daha ilk günlerde Milli Mücadele'nin meşruluğunu ilan ediyordu ${ }^{26}$. Başlangıçta Bolu Mebusu daha sonra Zonguldak'ın bağımsız liva olmasıly bu yer mebusu olarak TBMM'nde de hizmet veren Abdullah Sabri Efendi27, aynı zamanda bu milli hareketi Devrek halkına benimsetmek için mücadele veriyordu. O, gerek camilerde gerekse düzenlenen mitinglerde yaptı̆̆ konuşmalarda Anadolu hareketini halka duyuruyor, ve onların Mustafa Kemal Paşa'nın yanında yer almalarını istiyordu ${ }^{28}$.

23 Müftü Hüseyin Efendi, Milli hareketi benimsemediği gibi, bu hareketin aleyhinde faaliyet gösteren din adamlarından biridir. O, Anadolu'da okunması, dağıtılması, yasaklanmıs olan Dürri-zade'nin fetvasını, Cide yakınlarından geçen vapurlardan elde ederek halka dağıtıyordı. Müftü Hüseyin Efendi'nin Milli Mücadele'ye karşı olan bu çalışmaları, Kastamone: Valisi Cemal Bey'in yerinde aldığı tedbirle önlenmiștir. Bu konuda daha fazla bilgi için bkz: N. Peker, tSVR, s. 170-171.

24 Müftü İbrahim Efendi, 1872 yılından Zonguldak merkez Çağlı köyünde doğmuștur. İlk öğrenimini kendi köyünde yaptıktan sonra, 1887 yılı sonunda, Orta öğrenimi için Ereğli'ye gitti. Burada, 3 yıl Ali Molla Medresesi'nde öğrenim gördü. Daha sonra, İstanbul'a giderek Süleymaniye Medresesi'nde eğitimine bașlayan İbrahim Efendi, buradan 21 Kasım 1903 yılında üstün başarı ile mezun oldu. Bu başarısından dolayı Gümüş madalya ile taltif edildi. Ibrahim Efendi, 15 Mayıs 1906'da Zonguldak Müftüsü olarak tayin edildi. Bu arada, 8 Mart 1913-19 Ağustos 1915 tarihleri arasında da vekaleten Zonguldak Kadılığı görevini de yürüten İbrahim Efendi Zonguldak Müftüsü iken, 15.1.1934 tarihinde vefat etti. (Diyanet İșleri Başkanlığı Arşivinde bulunan özlük dosyasından).

25 Cevat Rifat Atilhan, "Milli Mücadele'nin Dört Sarıkh Kahramanı "Sabil ürreşat C. II, s. 37, (Mart 1949) s. 187-188; Cevat Atilhan, "Vurun Kahpeye" Sebilürreşad, s. 41 (Nisan 1949) s. 249-259; Kadir Misıroğlu, Kurtulus Savaşında Sarıklı Mücahitler, 2. baskı, İstanbul, 1969, s. 197-199.

26 Abdullah Sabri Efendi, 152 Müftü ve Müderris arasında 46. olarak "Fetva-yı Şerife"yi imzalamıștır. Bkz. Hakimiyet-i Milliye, 5. Mayıs 1336.

27 Abdullah Sabri Efendi, 1872, yılında Devrek'te doğdu. Hacı Mehmet Efendi'nin oğlu olan Abdullah Sabri Efendi Devrek'te Şeyh ve Müftü iken 48 yaşında Milletvekili seçildi. Şeri'ye ve Irşâd Encümenleri'nde görev aldı. (Türkiye Büyük Millet Meclisi'nin 25. $\Upsilon_{l} l$

Dönümünü Anļ̧ (25 Nisan 1945) s. 10 .

28 A. Sarikoyuncu, agt, s. 99. 
Yörede bu şekilde din adamları önderliğinde başlayan bağımsızlık mücadelesine belediye başkanlarının da katılmakta gecikmediklerini görüyoruz. Hatta birlikte çalışmışlardır. Bu müşterek çalışmalarını Heyet-i Temsiliye Başkanlığı ile yaptıkları yazışmalarda'dahi görmek mümkündür ${ }^{29}$.

Belediye başkanları ve din adamlarının belirttıldiği şekilde birlikte çalışmaları sonunda Zonguldak ve havalisinde de Milli Mücadele fikri doğmaya başlamıştır. Ancak bu fikrin fiiliyata geçmesi ise, aşağıda izah edileceği üzere, yörede Müdafaa-i Hukuk Cemiyetleri nin kurulmasıyla olmuştur.

\section{Müdafaa-i Hukuk Gemiyetlerinin Kuruluşu ve Faaliyetleri}

Türk Milleti'nin haklı sesini dünyaya duyurmak için Sivas'ta milli bir kongrenin toplanmasını gerekli gören Mustafa Kemal Paşa, ilk işareti daha 22 Haziran $1919^{5}$ da Amasya'dan vermişti. Paşa, bu husustaki talimatını çektiği telgraflarla askeri makamlar ile vali ve mutasarrnflara bildirmişti ${ }^{30}$. O, ayrica İstanbul'da bulunan ve milli hareketle ilgilenmelerini istediği kişileri de özel mektupiar yazarak hizmete çağırmıştı ${ }^{31}$.

Sivas Kongresi, önceden tesbit edildiği gibi 4-12 Eylül 1919 tarihleri arasında toplandı. Kongre 7 Eylül 1919 günü aldığı kararla; Anadolu ve Rumeli'de kurulmuş olan bütün Müfadaa-i Hukuk-u Milliye Cemiyetleri'ni, "Anadolu ve Rumeli Müdafaa-i Hukuk Cemiyeti" adını taşıyan tek cemiyet haline getirdi ${ }^{32}$. Hemen cemiyetin tamamı

29 25.9.1919'da Zonguldak'tan Sivas'a (Heyeti Temsiliye Başkanlığı'na) çekilen telgraf Müftü Ibrahim Efendi ile Belediye Başkanı Ibrahinı Bey'in imzalarını taşımaktadır. Bkz. Ek: 1, 1/a, 1/b Aynı şekilde; Bartın (Müftü: Rifat, Belediye Başkanı: Ziya) ve Ereğli (Müftü: Mehmet, Belediye Başkanı Hüseyin)'den de gönderilen yazılar da bu yerlerin Müftü ile Belediye Başkanlarının imzaların taşımaktadır. Bu konuda bkz.: Cuım. A: III/3 D:14, Fh: 45-10; ATASE Ata. Arș. Kl: 10, D: 335 /24-32, Ff: 24-2.

30 M. Kemal Atatürk, Nutuk, C. I, Bugünkü Dille Yayına Hazırlayan Prof. Dr. Zeynep Korkmaz, Atatürk'ün Doğumunun 100. Yılını Kutlama Koordinasyon Kurulu Yay. s. $21-22$.

31 Mustafa Kemal Paşa tarafından hizmete şağrılan kimseler şunlardır: Abdurrahman Şeref Bey, Reşit Akif Paşa, Ahmet İzzet Paşa, Seyit Bey, Halide Edip'Hanım, Kara Vasıf Bey, Ferif Bey, Cami Bey ve Ahmet Riza Bey'dir (a.g.e. C.I. s. 24).

32 Sivas Kongresi'nde alınan diğer kararlar için bkz: Enver Ziya Karal, Türkìye Cumhuriyeti Tarihi (1918-1965), Ankara 1978, s. 39-40.

33 "Anadolu ve Rumeli Müdafaa-i Hukuk Cemiyeti Teşkilatı Hakkında Talimatname" adı altında yayımlanan bu talimatnamenin tamamı için bkz.: Tarih Vesikaları Sayı 15 (Mayıs 1949) s. 160-170. 
dokuz maddeden ibaret olan talimatnamesi hazırlandı. Bu talimatnamenin 2. maddesine göre; Cemiyetin köy, nahiye, kaza ve vilayetlerde birer teşkilaıı bulunacaktı. Aynı zamanda bunlar birbirlerine bağlı idi. Vilayet teşkilatı; taşra da en üst kuruluş durumundayd1 ${ }^{33}$.

Mustafa Kemal Paşa; Heyet-i Temsiliye adına bu cemiyetin talimatnamesinde belirtilen şekilde örgütlenmesi için Valilik ve Mutasarrıflıklara emirler vermişti. Ancak, Kastamonu Posta Telgraf Başmüdürü Şeyh Ramiz Efendi ${ }^{34}$, Vali Vekili Osman Nuri Bey'i ${ }^{35}$ iğfal ederek Heyet-i Temsiliye'den gelen telgrafları muhaliflere ulaştiriyordu ${ }^{36}$.

Öte yandan Vali İbrahim Bey İstanbul'da tutuklanmıs yerine Padişah yanlısı Ali Rıza Bey adında birisi Kastamonu Valisi olarak tayin edilmişti. Bunu Sivas'ta 'öğrenen Mustafa Kemal Paşa, Kastamonu'ya yeni bir mintıka Komutanı atanmasinı ve duruma hakim olmasını 20. Kolordu komutanı Ali Fuat Paşa'dan rica etti. Bunun üzerine; Albay Osman Bey Kastamonu Mintıka Komutanı olarak atandi. Osman Bey, şehire girerken Hilafetçiler tarafindan yakalanıp esir edilmiş ise de; sonra kurtularak 16 Eylül 1919 gecesi idareyi eline almayı başardı. Vali vekilliğine de Defterdar Ferit Bey atandı ${ }^{37}$.

Ferit ve Osman Beyler Mustafa Kemal Paşa ile görüştüler ${ }^{38}$. Ferit Bey, Paşa'dan aldığı emirle Anadolu ve Rumeli Müdafaa-i Hukuk Cemiyeti'nin Kastamonu ve çevresinde örgütlenmesine girişti ${ }^{39}$. Fakat 17 Eylül 1919`da Bolu İstanbul ile olan irtibatını henüz kesmemişti. Bunun üzerine Mustafa Kemal Paşa Albay Osman Bey'e, Bolu Mutasarrıfı'na İstanbul ile olan bağlantısını koparması hususunu bildirmesi talimatını verdi 40 .

Mintıka Komutanı Paşa'dan aldığı bu emri hemen Bolu Mutasarrıflığına ulaştırdı. Ancak Mutasarrıf Ali Haydar Bey İstanbul ile

34. Şeyh Ramiz Efendi koyu bir Hilafetçi iai (Kamil Erdeha, Milli Mücadelede Vilayetler ve Valiler, Remzi Kitabevi İstanbul 1975, s. 213).

35 Osman Nuri Bey, Kastamonu Jandarma Komutanı olup, Vali Ibrahim Bey'in 4 Ağustos 'da ayrılmasıyla onun yerine Vali Vekilliğine getirilmişti. Osman Nuri Bey, temiz, dindar halim selim olmasına rağmen siyasi yönü eksikti (K. Erdeha, Milli Mücadele' ¿c Valiler ve Vilayetler, gös. yer.).

36 N. Peker, ISVR, s. 60; K. Erdeha, Milli. Mücadele'de Valiler, s. 213.

37 N. Peker, ISVR, s. 60; K. Erdeha, Milli Mücadele'de Valiler.. s. 213.

38 Bu konuda daha fazla bilgi için bkz. N. Peker, ISVR, S. 63-86; K. Erdeha, Milli Mücadele'de Valiler..., s. 215-216.

39 Bu görüşmeler için bkz. Nutuk, C. III, s. 72-75. Belge No: 106.

40 K. Erdeha a.g.e., s. 217. 
ilişkileri kesme işini savsakladı. Bunun üzerine Mithat Kemal (ALGÜLOĞLU) ${ }^{41}$ derme çatma silahlı güçlerini yanına alarak telgrafhaneye gitti ve Bolu eşrafinı yanına çağırttı. Burada Mithat Kemal Bey, gelenlere Sivas Kongresi'nin aldığı kararları açıkladı. Ayrıca, İstanbul ile olan irtibata son verilmesi gerektiğini anlattı. Aynı zamanda İstanbul'a durumu 22 Eylül 1919'da çektiği telgrafla bildirdi. Telgrafi Bolu Mutasarrıfı olarak imzalamaktan çekinmedi. Bütün bu olaylar olurken, Mutasarrıf Ali Haydar Bey hasta olduğu gerekçesiyle evinde bulunuyordu. Böylece Kastamonu'dan sonra Bolu livası da İstanbul ile olan ilişiğini kesiyordu ${ }^{42}$.

Bundan sonra Mithat Kemal Bey'in liva ilçelerine birer telgraf gönderdiğini görüyoruz. $\mathrm{O}$ bu telgraflarında; "Ulusal isteğe karşı koyan Ferid Paşa Kabinesiyle ilişiğin kesildiğine değin Padişah'a telgraf çekilmesi ve telgrafin çekildiğine değin cevabın beklendiğini bildirdi" 43 .

Mithat Kemal Bey'in telgrafları çevrede etkisini göstermekte gecikmedi. Nitekim 25 Eylül 1919 tarihinde Zonguldak Müftüsü İbrahim Efendi ile Belediye Başkanı İbrahim Bey'in imzalarıyla Heyet'i Temsiliye Başkanlığına gönderilen yazıda Ferit Paşa Hükümeti protesto edilmekteydi ${ }^{44}$. Aynı gün Mütekait Yüzbaşı Ethem Bey de Sivas'a çektiği telgrafinda; Mustafa Kemal Paşa'dan milli hareketin yörede gelişmesi için kiminle irtibat kuracağını soruyordu ${ }^{45}$. Bartın'dan da 26.9.1919 tarihinde Müftü Rifat Efendi ile Belediye Başkanı Ziya Bey'in imzalarıyla Heyet-i Temsiliye Başkanlığı'na bir telgraf gönderilmiştir ${ }^{46}$. Bu telgrafta da; Milli harekete karşı çıkan Ferit Paşa kabinesinin düşürülmesi girişimi Bartın ahalisi tarafindan takdir

41 Mithat Kemal (ALGƯLOĞLU); 1889 yılında Ankara'da doğmuştur. 1911 yılında, Mülkiye Mektebini bitirmiştir. Ankara maiyyet memuru olarak bir müddet çalıştıktan sonra, Bolu Livası Daimi Encümen Katipliği'ne, oradan da Temmuz 1914'de, Çarşamba Bucak Müdürlüğü'ne atandı. Tekrar Bolu’ya gelerek Encümen Başkatibi oldu. (Ali Çankaya, a.g.e. C. IV, s. 1367); Ayrıca; Mithat Kemal Bey, İstanbul Hükümeti’ne karşıydı. Çevresinde "Küçük Mithat" olarak tanınan Mithat Kemal Bey'in "Ayanlar Devrinde Bolu" adında bir kitabı vardır (K. Erdeha, "Milli Mücadele de Livalar...'s. 38-39)..

42 M.Z. Konrapa, a.g.e., s. 723; R. Apak, a.g.e., s. 118; Mithat Kemal Bey, 21 Eylül 1919 tarihinde de Mustafa Kemal Paşa'ya gönderdiği telgrafıyla Ferit Pașa Hükümeti'nden şikayetçi olmaktaydı (ATASE Ata Özel Arş, Kl: 15, D: 1335/35-2-48 Fh: 38 43 K Erdeha, Milli Mücahedele'de livalar s 38

44 Gum. A: III/3 D: 142, Fh: 43, 43-1. 43-2

45 ATASE Ata Özel Arş., Kl: 2, D: 1335/3-2, Fh: 44-1.

46 Bu telgrafta; Bartın Rum Ruhaniyesi Reisi'nin de imzası bulunmaktadır. 
edildiği belirtildikten sonra, bu konuda "usulüne uygun olarak Padişah'a telgraflar gönderildiği” bildirilmekteydi ${ }^{47}$.

Mithat Kemal Bey önderliğinde Bolu merkezinde başlayan bu milli çalışmalara kısa bir süre sonra Mutasarrıf Ali Haydar Bey de katıldı. Nitekim Ali Haydar Bey., 29 Eylül 1919 tarihinde Mustafa Kemal Paşa'ya gönderdiği telgrafinda "Emr-i devletleri harfiyen infaz edilmektedir" 48 demektedir. Ayrica Ali Haydar Bey, 9 Ekim 1919 'da Mustafa Kemal Paşa'ya telgraf göndererek başarılarını kutlamıştır ${ }^{49}$.

Diğer taraftan 27 Eylül 1919 tarihinde de Mudurnu İlçesi Mithat Kemal Bey'in yukarıda zikredilen telgrafina uyarak İstanbul ile ilişkisini kesmiştir ${ }^{50}$. Ayrıca; 15 Ekim 1919'da Dr. Fuat Bey başkanlığında Bolu Müdafaa-i Hukuk Cemiyeti de kurulmuştur ${ }^{51}$.

Bu gelişmelerin sonunda Zonguldak ve havalisinde de Müdafaa-i Hukuk Cemiyetleri kurulmaya başlanmıştır. Şimdi bu cemiyetlerin örgütlenmelerini görelim:

\section{A. Zonguldak Müdafaa-i Hukuk Cemiyeti}

Daha önce Emekli Yüzbaşı Ethem Bey'in 25 Eylül 1919'da Sivas'a telgraf çekerek Mustafa Kemal Paşa'dan bilgi istediği belirtilmişti.

Mustafa Kemal Paşa da; Anadolu ve Rumeli Müdafaa-i Hukuk Cemiyeti Temsiliyesi Heyeti adına, Emekli Yüzbaşı Ethem Bey’e 26.9.1919 tarihli telgrafi ile cevap vermiştir. Bu telgrafta; Ethem Bey'e Kastamonu havalisi Komutanı Osman Bey veya Bolu Mutasarrıfi Haydar Bey ile "te'sis-i irtibat" olunabileceği bildiriliyordu. Ayrıca; gizli haberleşmeler için de Osman Bey'e müracaat edilmesi talimatı veriliyordu ${ }^{52}$.

Ethem Bey'in bu çalı̧maları sonunda; 28 Ekim 1919 tarihinde Ethem Bey'in başkanlığında Müftü İbrahim, Dr. Nihat, Orman-Fen Memuru Ali Rıza ve Dava Vekili Hüseyin Beyler'den müteşekkil Zon-

47 Cum. A: III/3, D: 14, Fh: 45-10. Ayrica bu telgrafın bir sureti de 3. Kolordu Komutanlığına gönderilmiștir. (Cum. A: III/3, D:14, Fh: 45-11)

48 Cum. A: III/3, D: 19, Fh: 55-11) Bu telgrafta ayrica; Adapazarinnn İstanbul ile olan ilişiğini kestiği bildirilmektedir.

49 ATASE Ata özel Arş., Kl: 8, D: 1335/19-27, Fh.: 36-16.

50 Selim Sarıbey, tstiklal Savaşında Mudurnu-Bolu-Düzce-Aydm, 1943, s .22-24

51 ATASE Ata Özel Arş Kl: 2, D: 1335/3-2 Fh: 73-4.

52 ATASE Ata. Arş. Kl: 2, D: 1335/3-2, Fh: 44. 
guldak Müdafaa-i Hukuk Cemiyeti kuruldu. Cemiyetin kuruluşu aynı gün Mutasarrif Ali Haydar Bey tarafindan Heyet-i Temsiliye Başkanlığı'na bildirildi ${ }^{53}$.

Zonguldak Müdafaa-i Hukuk Cemiyeti kısa bir süre Ethem Bey'in başkanlığında faaliyet gösterdi. Daha sonra başkanlık görevini Müftü Ibrahim Efendi üstlendi54. 22.3.1921 tarihinde "BMM Reisi Mustafa Kemal Paşa Hazretlerine” gönderilen telgraftan anlaşıldığına göre, bu tarihlerde Zonguldak Müdafaa-i Hukuk Cemiyeti yönetim kurulu şu şahıslardan oluşmaktaydı. Başkan: Müftü İbrahim Efendi, Üyeler; Ahmet Ali Zade Ali, Hacı Bekir Zade Fevzi, Belediye Başkanı Ibrahim, İkdisat Müfettişi Bedri, Mamurat-ül Aziz Jandarma Alayı'ndan Mütekaid Ethem ve Orman Muamelat Memuru İhsan Efendiler'dir ${ }^{55}$.

Bu cemiyetin özellikle Müftü İbrahim Efendi'nin Kuva-yı Milliye'nin ikmali hususunda 56 ve yöre halkının şuurlanmasında fevkalade hizmeti olmuştur. Müftü Efendi, ilerlemiş yaşına rağmen at sırtında yöre yerleşim yerlerini köy köy, kasaba kasaba dolaşarak halkı, askere çağrılan gençleri ve din görevlilerini Milli Mücadele için seferber etmiştir ${ }^{57}$.

Zonguldak Müdafaa-i Hukuk Cemiyeti, bu hizmetlerinin yanısıra, zaman zaman yöre hakkında Büyük Millet Meclisi Hükümeti'ne raporlar göndermiştir. Bunlardan Genelkurmay Askeri Tarih ve Stratejik Etüd Başkanlığı Arşivi'ndeki rapor önemlidir ${ }^{58}$.

“Ankara'da Müdafaa-i Hukuk-u Milliye Heyet-i Temsiliye Riyaseti'ne" başlığını taşıyan bu rapor; 17 Temmuz 1920 tarihli olup, Zonguldak Müdafaa-i Hukuk Cemiyeti Heyet-i Merkeziyesi Reisi Müftü İbrahim imzasını taşımaktadır.

53 ATASE Ata . Arş. Kl.: 2, D: 1335/3-2, Fh: 83.

54 Atatürk Özel Arşivi'nde rastladığımız 3.12.1919 tarihli bir belgede (Bu yazı Zonguldak Müdafaa-i Hukuk Cemiyeti Başkan Müftü İbrahim Efendi tarafından Mustafa Kemal Paşa'ya gönderilmiştir.) Müdafaa-i Hukuk Cemiyeti Başkanı olarak Müftü İbrahim Efendi'nin imzasını taşımaktadır. (ATASE Ata. Arş. Kl: 10, D:335/24-22 Fh.: 54).

55 Cum. Arş. A: 111-3, D:14 Fh: 14-3, 14-4. Ayrica "Milli Mücadele Döneminde Müdafaa-i Hukuk Cemiyeti Teşkilatları" adlı incelemede de ayn isimlerden söz euilmektedir. Bu konuda bkz. "Milli Mücacele Döneminde Müdafaa-i Hukuk Cemiyeti Teşkilatları" BTTD, Sayı: 19 (Eylül 1986) s. 14.

56 Bu konuda bkz: A. Sarkoyuncu agt s. $277 \mathrm{vd}$.

57 Açık Söz, 2 Eylül 1336, s. 4; Cevat Rifat Atilhan, tstiklal Harbinde Sarıklı Kahramanlar, Yaylacık Matbaası İstanbul, 1967, s. 71. Müftü İbrahim Efendi’nin yöredeki bu gezilerine zaman zaman Zonguldak Müdafaa-i Hukuk Cemiyeti üyelerinden Ethem ve Ali Rıza Beyler de katılmıştır. (A̧̧ıı Söz, gös. yer.)...

58 ATASE Arş. Kl: 563, D: 14, Fh: 1, 1-1, 1-2, 1-3. 
Tamamı dört büyük sayfadan ibaret olan bu raporun giriş kısmında; Zonguldak'taki Fransız, İtalyan ve İngiliz nüfuz bölgeleri hakkında bir hayli geniş bilgiler verilmektedir.

Raporun daha sonraki kısmında ise, Zonguldak'ı işgal eden Fransız askerlerinin faaliyetlerini özellikle Fransız askerinin sayısı ve askeri araç ve gereçleri hakkında bilgiler sunulmaktadır.

Ayrıca; Fransız işgaline karşı Müdafaa-i Hukuk Cemiyeti olarak yaptıkları ve yapmakta oldukları hizmetlerden özellikle; Müslüman Fransız müstemleke askerlerinin firarlarının sağlanması için verilen çabalardan, firar eden Fransız asker sayısı ve onların Zonguldak'taki Fransız faaliyetleri hakkında verdikleri bilgileri ihtiva etmektedir.

$\mathrm{Bu}$ arada; Kuva-yı Milliye için yapılan ve yapılmakta olan ikmal faaliyetlerinden de söz edilmektedir. Hatta bu kısımda; Kuva-yı Milliye'nin ikmali için Zonguldak'tan ihraç edilmekte olan kömürlerin beher tonundan Müdafaa-i Milliye adına birer lira alınması hususunda Büyük Millet Meclisi Hükümeti'nce bir "Kanun-u muvakkat" (Geçici Kanun) çıkarılması ve ayrıca; Kuva-yı Milliye'ye yapılan ikmal faaliyetlerinin daha düzenli olması ve arttırılması için Hilal-i Ahmer'in Zouguldak'ta bir şubesinin açılması teklif edilmektedir.

Raporda haberleşmedeki özellikle Büyük Millet Meclisi ile olan muhaberatta çekilen sıkıntılar ve Zonguldak halkından da söz edilmektedir. İbrahim Efendi, raporunun bu kısminda; Zonguldak halkının bazıları arasında menfaatın ağır bastığını belirterek “... pek çok kimseler şirkete (Fransızlara), satılmıs gibidir"59 demektedir.

Raporun son bölümünde müşkilleri olduğundan bahisle, bu rapora ve bundan sonraki gönderecekleri raporlara önem verilmesi talep edilmektedir. Raporun sonunda ise; bir nevi özel not şeklinde Fransız Müslüman askerlerinden 40 kişinin daha firar ettiği haber verilmektedir.

$\mathrm{Bu}$ raporun suretleri; ihtiva ettiği bilgiler sebebiyle; 29.7.1920 tarihinde, Genelkurmay Başkanlığı'nca, Milli Savunma, Maliye ve İçişleri Bakanlıklarına gönderilmiştir ${ }^{60}$.

Bu rapor, bir bakıma Zonguldak Müdafaa-i Hukuk Cemiyeti'nin faaliyetlerinin büyük bir kısmını da özetlemektedir. Hiç kuşkusuz;

59 ATASE Arş., KL: 563, D: 14, Fh: 1-2. Buradaki şirket sözcüğü ile Müftü İbrahim Efendi Fransız Ereğli Şirketi'nden sözetmektedir.

60 ATASE Arş., KL: 563, D:14, Fh: 1. 
Cemiyetin yörede verdiği ve yukarıda kısaca değinilen hizmetlerin hemen hepsi önem arzetmektedir. Hele Milli Mücadele'nin ilk yıllarındaki yörenin sosyo-ekonomik durumu ve işgal altında bulunması da göz önünde bulundurulursa; Zonguldak Müdafaa-i Hukuk Cemiyeti'’nin hizmetlerinin büyüklügü daha da artmaktadır.

\section{B. Bartın Müdafaa-i Hukuk Gemiyeti}

Mondros Mütarekesi sonrasında Fransizların 8 Mart 1919'da Zonguldak'a asker çıkarmalarının yanısıra, Bartın sahillerinin de İtilaf gemilerinin tehdidine girmesi, halk1 tedirgin etmekteydi61.

Ayrıca; daha önce belirtildiği gibi Bolu Mutasarrıflı̆ğ da 22 Eylül 1919'da İstanbul Hükümeti ile olan ilişkisini kesmişti. Kastamonu Valiliği ise, daha ilk günlerden itibaren Milli Mücadele saflarında yer almişt1 ${ }^{62}$.

Diğer taraftan Bartın gençleri de Samancıoğlu Galip Bèy Başkanlığında ${ }^{63}$ Temmuz 1919 'da kurdukları Illim ve İfan Derneği ile bir örgütlēnmeye gitmişlerdi ${ }^{64}$. Bu dernek, eğitim ve öğretim faaliyetlerinin ${ }^{65}$ yanısıra; Müdafaa-i Hukuk gayeleri etrafindan da çalışmaktan geri kalmamıştı ${ }^{66}$. Bu çalışmaların da etkisiyle Bartın halkı özellikle gençleri Milli Mücadele lehinde bilinçlenmeye başlamışlardı ${ }^{67}$.

Bütün bu gelişmelerin bir sonucu olarak, daha önce değişik vesilelerle de sözedildiği gibi, 26 Eylül 1919 tarihinde Bartın halkının ileri gelenleri Belediye Başkanı Ziya, Müftü Rifat Efendi ve Rum Reisi Ruhanisi Gavril Efendi., Heyet-i Temsiliye Başkanlığı'na çektikleri telgrafla Milli Mücadele saflarında yer aldıklarını göstermişlerdi68. Mustafa Kemal Paşa da bu telgrafa; Bartın Belediye Başkanlığı'na gönderdiği 30 Eylül 1919 tarihli telgrafla cevap vermiştir. Paşa bu telgrafinda; Ferit Paşa Hükümeti aleyhinde gösterilen tepkiden dolayı teşekkür ettikten sonra, “Teşkilat-1 Milliye'nin Bartın'da da kurulma$\sin 1$ istemekteydi ${ }^{69}$.

61 ATASE Arș. Kl: 559, D: 6, Fh: 26-6; ATASE Arș. Kl: 952, D:13 Fh: 12.

$62 \mathrm{Bu}$ konuda daha fazla bilgi için bkz., N. Peker, ISVR, s. $62-86$.

63 Derneğin diğer yönetim kurulu üyeleri ise, şu zevattan oluşmaktaydı: Avukat Hasan Bey, (II. Başkan) Doktor Cevdet Bey (Aza), Komisyoncu Şükrü Efendi (Aza), ve tüccardan Únyelizade Kazım Efendi (Veznedar),

641920 Temmuz'unda Bartın İlim ve İrfan Derneği'nin ikinci yıla başlaması dola-

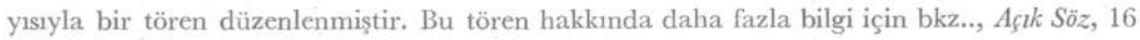
Ağustos 1336. 
Bunun üzerine, Milli hareketi benimseyen halkın desteğinde Bartın Müdafaa-i Hukuk Cemiyeti, 15 Ekim 1919 tarihinde faaliyete geçti. Cemiyet, geçici idare heyeti yönetiminde hemen çalışmalarına başladi. Aynı gün de Sivas'ta bulunan Mustafa Kemal Paşa'ya durum bildirildi ${ }^{70}$. Mustafa Kemal Paşa da aynı tarihte geçtiği telgrafla cemiyetin yönetim kuruluna başarılar dilemekteydi ${ }^{71}$.

$\mathrm{Bu}$ şekilde geçici idare heyeti yönetiminde çaliş̧malarına başlayan Bartın Müdafaa-i Hukuk Cemiyeti, daha sonraki günlerde şu zevatın yönetiminde faaliyetlerini sürdürdü; Yusuf Ziya Bey (Başkan), Karakaşoğlu Rahmi Bey, Yirmibeşoğlu Hasan Bey, Müftü Hacı Rifat Efendi, Hacı Arif Kaptan, Samancioğlu Hüseyin Efendi, Paşa Mehmetoğlu Mustafa Bey, Fırıncıoğlu İbrahim Fuad Bey, İncealemdarzade Halil Bey ve Hacıbalıkzade Hacı Mehmet Efendi'dir ${ }^{72}$. Cemiyet, 18 Ocak 1920 tarihinde de "Bartın Müdafaa-i Hukuk Heyeti" adını almıştır ${ }^{73}$.

Bartın'daki Milli Mücadele lehindeki bu gelişmelere rağmen, hala halkın bir kısmı İstanbul Hükümeti ile ilişki içerisinde bulunuyordu. Hiç kuşkusuz Bartın halkının bu şekilde ikiye ayrılmasında; Hürriyet ve İtilaf Fırkasının yanısıra; Kaymakam Durmuş Bey'in de davranışları etkili olmaktayd $\mathbf{1}^{74}$.

$65 A_{\xi ̧ ı l}$ Söz'de Bartın İlim ve İrfan Derneği'nin faaliyeîlerinden șöyle sözedilmektedir: ". . . Bir kütüphanede toplanarak ilmi, fenni, ictimai münakaşalar, müsahabeler tertip ve terbiye-i ilmiyyenin inkişafına hizmet etmeyi ve köylünün bütün dertlerini teşrih, ruhen ve cismen tedavisine çalışmayı gaye edinen (dernek) ikinci sene-i hayatı için daha ziyade faaliyet göstermek azmini besli jor". Açık Söz., 16 Ağustos 1336.

66 Hüsnü Açısözcï, a.g.e., s. 79.

67 Bartın gençlerinin milli harekete karşı ilgileri ve Kuva-yı Milliye'ye hizmetleri içın bkz. Açık Söz, 16 ağustos 1336.

68 Cum. Ars, A: II1/3, D:14, Fh: 45-10, 45-11.

69 Cum. A: III-3, D: 15, Fh: 1

70 "Sivas Anadolu ve Rumeli Mürafaa-i Hukuk Cemiyeti Riyasetine hitabı ile bașlayan bu telgrafta; "Kazamızda Cemiyeti Heyeti İdare-i Muvakkatesi’ni teşkil ediyoruz." denilmektedir. Ayrıca telgraf "Heyet Reisi Muvakkatesi Tahsin imzasını taşımaktadır" (ATASE Ata. Arş. Kl: 2, D: 1335/3-2, Fh: 75.

71 Mustafa Kemal Paşa, "Bartın Anadolu ve Rumeli Müd̦afaa-i Hukuk Cemiyeti İdaresi Riyasetine" hitaben çekilmiş telgrafında şöyle diyordu;

"Kazanızca teşki!-i iş'ar buyurulan Heyet-i İdareye muvaffakiyetler temenni ederiz efendim" (ATASE Aț. Arş. Kl: 2, D: 1335 '3-2, Fh: 75-1.

72 Kemal Samancıoglu Iktisat ve Ticaret Bakımmdan Bartın, Bartın-1942, s. 24; Erkan Aşşığlı, Bartın Ticaret ve Sanayi Odası yayını, Ankara 1984, s. 14; Sakaoğlu a.g.e., s. 165166.

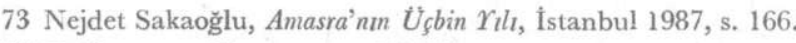

74 K. Samancioğlu, a.g.e., s. 23-24. 
Bu bakımdan kuruluş günlerinde Bartın Müdafaa-i Hukuk Cemiyeti üyeleri zorluklarla karşlaşmışlardır. Ancak cemiyetin bu s1kıntılı günleri pek uzun sürmedi. Zira 1 Haziran 1920 tarihinde kuvvetleri ile birlikte Bartın'a gelen Yzb. Cevat Rifat Bey ${ }^{75}$ tarafindan Kuva-yı Milliyeci Hüsnü Bey, buraya Kaymakam olarak atanmı̧̧tı $^{76}$. Yeni Kaymakam Hüsnü Bey ise, kısa zamanda büyük küçük herkesin saygı ve sevgisini kazanarak Bartın halkında "Kuva-yı Milliye'ye karşı bir hissi hürmet uyanmasını" sağlamıştır. Ayrıca $\mathrm{O}$, kent halkı arasında birlik ve beraberliğin temininde de etkili olmuştur ${ }^{77}$. Hiç şüphesiz Hüsnü Bey; Milli Mücadele açısından son derece önemli olan hizmetlerinde, destek ve yardımcı olan Bartın Müdafaa-i Hukuk Cemiyeti özellikle cemiyet başkanı Yusuf Ziya (Özençi)'dir ${ }^{78}$.

75 Cevat Rifat Bey, Bartın ve Havaisi Komutanı'dır. Bu komutanlık hakkında bkz. A. Sarıkoyuncu, agt, s. 121-126.

76 Kaymakam Durmuş Bey, Cevat Rifat Kuvvetleri Bartın'a gelmeden önce Amasra'ya çekilmiști (N. Peker, ISVR s. 195).

77 Açık Söz'de Kaymakam Hüsnü Bey'in başarılarından şöyle söz edilmektedir: “.... Kaymakam Bey vatandaşlar arasında ittihad ve uhuvvetin te'sisine çalı̧̧arak düne kadar yek diğeriyle teşrik-i miesaiden çekinen zevatı birleştirmiş ve bu sayede cidden hayrat efza teşebbüslerde muvaffak olmuştur... Buraya geleli henüz iki ay olmadığı halde büyük küçük herkesin hürmet ve muhabbetini celb etmiş olan Kaymakam Bey'in seheri müfitini teşriha kalkışmak zaid olur. Etrafında memurin ve eşraftan mürekkeb bir hale-i faaliyet ve hamiyyet teşkile muvaaffak olan mumaileyhin azm ve irşadı tedbir ve kıyâseti iledir ki, efradın istirahatı temin, techizâtı ikmaı edilmiş ve herkeste Kuva-yı Milliye'ye karşı bir hissi hikmet uyarmasına muvaffakiyet hasıl olmuștur..." (A̧̧.k Sŏz, 16 Ağustos 1336).

78 Yusuf Ziya (Özenci) Bey; 1875’be Dobriç’te doğdu. Illk ve Orta öğrenimini Bartın'da yaptr. Daha sonra, İstanbul'da Bahriye Okulu'nda öğrenim gördü. Bu okuldan makine mühendisi olarak mezun olan Yusuf Ziya, siyasetle ilgilendi. Osmanlı Meclis-i Mebusanı'nda II. ve III. dönemlerde Bolu Mebusu, TBMM'inde de II.VI. ve VII. dönemlerde ise Zonguldak Milletvekili olarak hizmet vermiştir. 10.1.1951'de ölmüş̧ür. (Türkiye Büyük Millet Meclisi Albümü, 23 Nisan 192014 Ekim 1973, Hazırlayan: Kazım Öztürk, Önder Matbaası, Ankara, 1973, s. 108.

Ayrıca yeğeni Orhan Göncüoğlu (Bayındırlık Bakanlığı Müsteşarlığı'ndan emekli); 24 Mayıs 1990 tarihinde Ankara-Küçükesat Büyükelçiler Sok. 18/9 daki evinde yaptığımız görüşmede Yusuf Ziya Bey hakkında şunları söylemiştir:

"Dayım Yusuf Ziya Bey, Bartın'dan Yüksek Öğrenim için İstanbul'a giden ilk kişidir. 16 Mart 1920'de Meclis'i Mebusan'ın kapatılması üzerine Mustafa Kemal Paşa tarafından Müdafaa-i Hukuk Cemiyeti ve Milli Mücadele için önemli hizmetlerde bulunmuștur. Dayım Yusuf Ziya Bey'in başkanı bulunduğu Ticaret'i Bahriye Türk Anonim Şirketi'nin Bartın iskelesinde yaptırdığı motor ve tekneler Kuva-vı Milliye'nin ikmalinde hizmet vermiştir. (O. Göncüoğlu, 1915 doğumlu olduğunu belirterek, o günlerde motor ve tekne inşası için yapılan çalışmaları kendisinin de hatırladığını belirtmiştir). Bu hizmetlerine mükafaat olmak üzere, Yusuf Ziya Bey, Mustafa Kemal Paşa'nın talimatıyla Zonguldak Milletvekili (II. Dönem) seçilmiştir". 
Aynı zamanda bu cemiyet, Yzb. Cevat Rifat Bey, yöreye gönderilinceye kadar milli hareketin Bartın ve çevresindeki tek temsilcisi idi. $\mathrm{Bu}$ arada Kuva-yı Milliye için göuüllü müfrezeler de teşkil edilmiştir ${ }^{79}$.

Bartın Müdafaa-i Hukuk Cemiyeti, bütün bu hizmetlerinin yanısıra, Kuva-yı Milliye'nin ikmali faaaliyetlerinde de bulunmuştur ${ }^{80}$.

\section{Devrek Müdafaa-i Hukuk Cemiyeti}

Mustafa Kemal Paşa Samsun'a ayak bastığı günlerde Devrek'te Milli Mücadele için çalışmalar başlamıştır. Bir ara Çaycuma'da Nahiye Müdürlüğü de yapmış olan Kadri Cemali Bey'in attığı Milli Mücadele kivilcımı ${ }^{81}$, Devrek Müftüsü ve Kadısı Abdullah Sabri Efendi'nin önderliğinde gelişti. Çünkü o, ilk günlerde gizliden yapılan Milli Mücadele çalışmalarını açıtan yürütmeye başlamışı. Camilerdeki konuşmaların yanısira Millet Bahçesi'nde de mitingler, toplantılar düzenliyordu ${ }^{82}$.

Abdullah Sabri Efendi'nin düzenlediği bu mitingleri görenlerden Mehmet Kara: "Bir gün, bu merkez camisinin önünde Hükümet Konağı vardı. Hükümet Konağı'nın yanıbaşında da bir kavak ağacı vardı. Orası bir kalabalık bir kalabalık. Biz bu ne dedik. O kaşları şöyle, gözleri fincan gibi çakmak çakmak heybetli bir kişi olan Abdullah Sabri Efendi masanın üzerine çıkmış, kılıç kuşanmış, Milli Mücadele için halkı konuşmaları ile galeyana getiriyordu"83 demektedir.

Hakkı Durna da; Abdullah Sabri Efendi’nin yaptığı mitingi şöyle anlatmaktadır: "Hatta bir gün büyük çınar ağaçlarının bulunduğu yerde (Oraya Millet Bahçesi denirdi) Abdullah Sabri Efendi elinde Sancak-1 Şerif olduğu halde konuşma yaptı" demektedir ${ }^{84}$.

Abdullah Sabri Efendi'nin oğlu A. Fahrettin Aytaç da babasınin Millet bahçesi'nde konuşma yaptığını belirterek bu konuda şunları söylemektedir: "Hatta babam halkı coşturmak için kılıç kuşanarak, Sancak-1 Şerifi, Sakal-1 Şerifi bile çıkarmıştı" demektedir ${ }^{85}$.

79 N. Sakaoğlu, a.g.e. s. 166.

$80 \mathrm{Bu}$ konuda daha fazla bilgi için bkz.; A. Sarıkoyuncu agt s. $281 \mathrm{vd}$.

81 A. Fahrettin Aytaç ve Hakkı Durna ile yapılan yayınlanmamıs röportajlar. Bkz; A. Sarkoyuncu agt, Ek: 15-16.

82 Aỵnı röportajlar.

83 Mehmet Kara ile yapılan yayınlanmamış röportaj. Bkz.: A. Sarıkoyuncu agt, Ek: 17.

84 Hakkı Durna ile yapılan röportaj. Bkz; A. Sarıkoyuncu agt, Ek: 16.

85 A. Fahrettin Aytaç ile yapılan röportaj. Bkz. A. Sarıkoyuncu agt, Ek: 15/a. 
Abdullah Sabri Efendi bu toplantılarda yaptığı konuşmalarda ise şöyle diyordu:

"Muhterem cemaat tüm yurdumuzda bu günden itibaren kurtuluş savaşı başlamıştır, Şimdi ise alacağınız karar ve çekeceğiniz telgrafla kadınımız, kızımız, topumuz, tüfeğimizle Mustafa Kemal'in yanında yer almalıyız" 86 . "İşte vatan elden gidiyor. Hep beraber kurtaracağı" "87.

Abdullah Sabri Efendi'nin aynı zamanda öğrencisi olan Beycuma Müderrisi Hüseyin Efendi ${ }^{88}$ de aynı konuşmaları köylerde yapmaktayd ${ }^{89}$.

Belirtilen çalı̧̧maların da etkisiyle Devrek halkı milli hareket taraftarı olmuştur. Hatta İlçe Kaymakam Şükrü Bey’e İstanbul Hükümeti ile olan ilişkisinin kesmesi hususunda baskı dahi yapmışlardı ${ }^{90}$.

Bu bakımdan muhtemelen yörede Müdafaa-i Hukuk Cemiyeti'ni ilk kuran ilçe merkezlerinden birisi Devrek'tir. Ancak bütün araştırmalarımıza rağmen Devrek Müdafaa-i Hukuk Cemiyeti'nin üyelerini ve kuruluş tarihini tam tesbit edemedik. Rastladığımız kaynaklarda sadece Devrek'te Osman Bey'in başkanlığında Müdafaa-i Hukuk Cemiyeti kurulduğu belirtilmektedir ${ }^{91}$.

Devrek'te görüştüğümüz kimseler ise; Müftü Abdullah Sabri Efendi, O Milletvekili olunca onun yerine Müftü olan Tahir Efendi, Selemen oğlu Hacı Süleyman Efendi, Kavakzade Hacı Emin Ağa,

86 Devrek Postası, Yıl: 12, S. 717 (13 Ekim 1982) s. 3.

87 Hakkı Durna ile yapılan röportaj. Bkz. A. Sarıkoyuncu agt, Ek: 16/a.

88 Devrek'in Hüseyin Çavuşoğulları köyünden.

89 Cevat Rifat Atilhan, Hüseyin Efendi'den şöyle sözetmektedir: "Küçük bir köy olan ve şimdi nahiye merkezi olmuş olan Beycuma'da Müderris Hüseyin Efendi yanıma geldi. Emrinize amadeyiz, malen, canen, bedenen ne yapmak lazım gelirse hiç bir fedakarlıktan geri durmayacağız. Yeterki düşman bu mübarek topraklardan ayağını çeksin ve vatan sükün ve selamete kavuşsun dedi

Küçük bir köyde oturan ve orada kendini yetiştirmiş olan bu sarılı Müderris Hüseyin Efendi'yi milletimin tanınmasını isterim. Türkçe ve Arapçayı anadili gibi bilirdi. Farsça da okur-yazardı. Fransızcası da mükemmel idi. Bize hizmeti de ilmi kadar geniş oldu" (Cevat Rifat Atilhan, "Milli Mücadelenin Dört Sarı.ı Kahramanı" Sebilürreşad, C. II, S. 17, Mart 1949, s. 188).

90 Hakkı Durna, amcası Sarı Mehmet'in Kaymakam Şükrü Bey’e "Ya İstanbul'la olan ilișiğini kesip Mustafa Kemal'e bağlanacaksın ya da Devrek 'ten gidersin.," diyerek tehdit ettiğini belirtmektedir. (Hakkı Durna ile yapılan yayınlanmamış röportaj. Bkz.; A. Sarkoyuncu, agt, Ek: 16.

91 Yurt Ansiklopedisi, C. 10, s. 7730, Devrek'te yaptığımız araştırmada bu kişinin Yeșilbaș Osman Efendi olduğunuzu tesbit ettik. 
Mekikzade Hacı Mehmet Efendi, Kitapsız İsmail Efendi, Kadir Cemali (Nahiye Müdürü) Bey, Yeşilbaş Hacı Osman Efendi, Mumyakmaz Hacı Osman Efendi, Dangöz İbrahim Efendi ve Hacı Abdullah Efendi'nin Müdafaa-i Hukuk Cemiyeti'nde çalıştıklarını belirtmektedirler ${ }^{92}$.

Devrek, Milli Mücadele esnasında Bolu-Gerede ile, Bartın-Zonguldak ve Ereğli arasında Kuva-yı Milliye lehine bir tampon bölge görevini üstlenmiştir. I. Düzce isyanının Bolu Gerede'den sonra Safranbolu'ya sıçradığı hatırlanırsa, Devrek'in Milli Mücadele için önemi kendiliğinden ortaya çıkar ${ }^{93}$. Muhtemelen halkının Milli Mücadele'ye verdiği tam destek sebebiyle Devrek; yöredeki Kuva-yı Milliye faaliyetlerinde karargâh görevi de yapmıştır ${ }^{94}$.

Öte yandan Devrek halkı, bu karargâha zarar gelmemesi için Dorukhan'da ${ }^{95}$. nöbet tutmuștur ${ }^{96}$. Aynı zamanda işgale uğrayan Ereğli'nin yardımına koşmuş̧ur ${ }^{97}$.

Bütün bu Milli Mücadele lehindeki çalışmaları organize edip yürüten hiç şüphesiz, Devrek Müfadaa-i Hukuk Cemiyeti'dir. Ayrıca bu cemiyetin yurtsever personeli gerek Devrek'ten ve gerekse Devrek üzerinden Batı Cephesi'ne yapılan ikmal faaliyetlerinde de hizmet vermiştir ${ }^{98}$.

Hemen belirtelim ki, Milli Mücadele için verilen bu hizmetlerde o yıllarda Devrek'in bir nahiyesi olan Çaycuma halkının da büyük yardımları olmuştur 99

$92 \mathrm{Bu}$ isimler, görüștüğ̈ümüz kimselerin hatırlayabildikleri kimselerdir: Bkz,; A. Sarıkoyuncu agt, Ek: 16/a, 18.

93 I. Düzce İsyanının Safranbolu'ya sıçraması hakkında bkz; A. Sarıkoyuncu agt, s 214-220.

94 Mesela Alemdar Gemisi olayında Fransız esirleri Devrek'e nakledilmiştir.

95 Dorukhan; Gerede-Mengen üzerinden Devrek'e $10 \mathrm{Km}$. uzaklıkta bir yer. Millî Mücadele yıllarında orada bir han bulunmaktaydı. Bu gün o hanın yıkıntıları hala mevcuttur.

96 A. Fahrettin Aytaç ile yápılan yayınlanmamıs röportai, Bkz; A. Sarıkoyuncu agt, Ek: $15 / \mathrm{b}, 16 / \mathrm{a}$

97 Fransızların Ereğli'den çıkarılmaları için Devrek'ten Muharrem Çetesi gitmiştir. (Hüseyin Başocakçı, Istiklal Savaşı ve 30 Ağustos Zaferi Nasıl Kazanıldı İlkadım Matbaası Zonguldak 1964, s. 5).

$98 \mathrm{Bu}$ konuda daha ayrıntılı bilgi için bkz.; A. Sarıkoyuncu, agt, s. 280-281.

99 A f̧ı Söz, 2 Eylül 1336. 


\section{Ereğli Müdafaa-i Hukuk Cemiyeti}

Daha önce de ifade edildiği üzere, Mondros Mütarekesi sonrası İtilaf güçlerinin işgalleri bütün yurtta olduğu gibi Ereğli'de de üzüntü ile karşılanmıştı.

Öte yandan 8 Mart 1919'da Fransızların Zonguldak'a asker çıkarmalarından, özellikle Yunanlılar'ın 15 Mayıs 1919'da İzmir'i işgal etmelerinden cesaret alan Ereğli Rumları taşkınlıklara başlamış$\operatorname{lardi}_{1} 100$.

Belirtilen durumlar, özellikle Mustafa Kemal Paşa'nın 19 Mayıs 1919'da Samsun'a çıkarak bütün yurtta Milli Mücadele'yi başlatması üzerine, Ereğli halkı da bu milli harekete katılmakta gecikmedi. Ancak, İstanbul Hükümeti’nin yoğun baskıları sebebiyle Ereğli halkı henüz mahalli milli direnme örgütlerini kuramamışlardı101.

Bu sebeple, halk açıktan Milli Mücadele'ye destek olamayışının üzüntüsü içerisinde idi. Bu bakımdan, Sivas Kongresi'nin bütün yurtta Müdafaa-i Hukuk Cemiyetleri kurulması yolunda aldığı karar Ereğli halkı için büyük bir firsat oldu.

İlçe halkının da isteği ile Ereğli Belediye Başkanı Akmanoğlu Raşit Bey, çevre köylere de haberler salarak Beyçayırı'nda toplandılar. ${ }^{102}$

Burada Rüşdiye öğretmenlerinden Nimet Bey bir konuşma yapt ${ }^{103}$. Nimet Bey bu konuşmasında şöyle diyordu:

"Milletin haysiyeti, şerefi, hürriyeti, istiklâli, gerçekten tehlikeye düşmüştür. Bu felaketten kurtulmak gerekirse, vatanın son ferdine kadar ölmeyi göze almak lazımdır. Padişah olsun, halife olsun, isim ve ünvanı ne olursa olsun hiç bir şahıs ve makamın hikmeti mevcudiyeti kalmamıştır. Yegane kurtuluş çaresi, halkın doğrudan doğruya eğemenliğini eline alması ve iradesini kullanmasıdır.

100 Bu konuda bkz; A. Sarıkoyuncu, agt, s. 192-195.

101 Eylül 1919 tarihinde İstanbul Hükümeti’nin Ereğli üzerindeki baskıları hala devam etmekteydi. Bu yüzden, Mustafa Kemal Paşa, 28.9.1919 tarihinde Sivastan gönderdiği telgrafıyla; Damat Ferit Paşa Hükümeti'nin Ereğli, Bolu, Adapazarı ve İzmit havalisindeki Kuva-yı Milliye'ye karșı olan tutumunu protesto etmektedir. (Cum. A: III/3, D:14, Fh: 51).

102 Nurettin Peker, Öl Esir Olma. Istiklal Savaşı'nda Ereğli Alemdar Gemisinin Kahramanlığl ve Sịasi Neticeleri, (ÖEO), İstanbul 1966, s. 127.

103 Nimet Bey, Ereğli halkının ilk günden itibaren Milli Mücadele yanında yer almasını isteyen ve bunun için çalışan bir kişidir (Tahsin Aygün, Kurtuluş Savaşında Karadeniz Ereğlisi, Tekıșık Matbaası, Ankara 1984, s. 8). 
Bizim burada alacağımız karar Mustafa Kemal'in " $Y a$ İtiklal, Ya Ölüm" direktifi ve yolunda gerçekleşecek olan ulusal iradenin egemenliği istikametinde ve Mustafa Kemal'in yolunda olacaktır"104.

Nimet Bey'in bu konuşmasından etkilenen halk Mustafa Kemal Paşa'nın emrinde çalışacağına and içti. Hemen Ereğli Müdafaa-i Hukuk Cemiyeti'nin kurulmasina karar verildi105.

Belediye Başkanı Akmanoğlu Raşit Bey başkanlığında106 kurulan Ereğli Müdafaa-i Hukuk Cemiyetinin üyeleri ise şu zevattan oluşmaktaydı: Nimet Efendi, Göbekoğlu Hakkı, Evvelzaman Hakkı, Hüseyin Ustaoğlu Nazif, Hacı Eyüp, Hacı Eşref, Cıbıroğlu Hacı Musa, Halil Ağa, Sarmısakcığlu Nazif, Haliloğlu Ali Rıza ve Karamahmutoğlu Mehmet'tir ${ }^{107}$. di 108 .

Ayrıca Müftü Mehmet Efendi de, cemiyetin kurucu üyelerinden-

Muhtemelen 1919 yılı Ekim ayında çalışmalarına başlayan ${ }^{109}$ Ereğli Müdafaa-i Hukuk Cemiyeti, Ereğli'nin Fransız işgalinden kurtarılmasında üstün hizmetler vermiştir110.

Ayrica Alemdar gemisinin kurtarılmasında ve Kuva-yı Milliye için Ereğli'den yapılan ikmal faaliyetlerinde de bu cemiyet üyelerinin hizmetleri olmuştur ${ }^{111}$.

\section{E. Safranbolu Müdafaa-i Hukuk Cemiyeti}

Mondros Mütarekesi sonrasında Itilaf devletlerinin Anadolu topraklarını işgal etmeleri, tüm yurtta olduğu gibi Safranbolu'da

104 T. Aygün, a.g.e. s. 9.

105 N. Peker, ÖEO, s. 127.

106 Nurettin Peker, cemiyetin Nimet Efendi başkanlığında kurulduğunu belirtmekte ise de; (N. Peker, OEEO, s. 127) bu doğru değildir. Aynı hataya Tahsin Aygün de düşmüştür. (Tahsin Aygün, Alemder Geliyor, Ayyıldız Matbaası İstanbul 1964, s. 13) Ancak Tahsin Aygün Bey kendisi ile yaptığım görüşmede bunun yanlışlıkla yazıldığını belirtmiştir. Nitekim Tahsin Aygün Bey, 1984 yılında basılan Kurtulus Savaşında Karadeniz Ereğlisi adlı eserinde (s.

10) Akmanoğlu Raşit Bey'in cemiyetin başkanlığına getirildiğini belirtmektedir.

107 N. Peker, ÖEO, s. 127.

108 Cemal Kutay, Istiklal Savaşııın Maneviyat Ordusu, C.I. Yelken Matbaası, Istanbul 1977 , s. 133.

109 Çünkü Bolu Mutasarrıflığı'nın İstanbul ile olan ilişkisini kestiği 22 Eýlül 1919 tarihinden sonra yörede Müdafaa-i Hukuk Cemiyetleri kurulmaya başlanmıştır. Daha önce belirtildiği gibi 15 Ekim 1919 tarihinde Bolu. 16 Ekim 1919'da Bartun ve 28 Ekim 1919'da da Zonguldak Müdafaa-i Hukuk Cemiyetleri kurulmuștur.

110 Bkz. A. Sarikoyuncu agt, s. 138-139.

111 Bkz. A. Sarkoyuncu agt, s. 150-158. 
da üzüntü ile karşılanmıştır. Nitekim Safranbolu Belediye Reisi Zühtü, İlçe Müftüsü Said, Eşraftan Hacızade Hasan, Eşraftan Veli Beyzade Mehmet , Eşraftan Mahmutzade Cemil, Eşraftan Akıllızade Hakkı, Tüccardan Hacı Salihzadẹ Ömer, Tüccardan Arap Hafizzade Hamdi ve Eşraftan Çobanzade Mustafa Beyler; 3 Haziran 1919 tarihinde Mustafa Kemal Paşa henüz daha Havza'da iken gönderdikleri telgrafla kanlarının son damlasına kadar düşmanla savaşmak istediklerini bildirmekteydiler.

Ayrica bu telgrafta, İtilaf güçlerince Türkiye'nin taksim edilmesi ardından da işgal edilmesi kınanmaktadır. Bu arada Wilson'un da adil davranmaması kınandıktan sonra, "Anayurdumuzu elimizden almak isteyenler bilmelidirler ki, biz Türkleri bir ferd kalıncaya kadar kesip bitirmeleri lazımdır, yoksa bu altıbuçuk asırlık vatan toprağını asla bizden alamazlar. Vatanımızın en küçük bir parçasının herhangi bir devlet tarafindan işgalini kemal-i azim hareketle protesto eder ve iş bu protesto namemizin Hükümet-i Matbuanızda aynen ilanını rica ediyoruz"112 denilmektedir.

Belirtildiği gibi halkının ileri gelenlerinin düß̧man işgallerine karşı tepki gösterdiği Safranbolu, Kastamonu'ya bağlıydı. Bu vilayet ise, o günlerde Milli hareket emrine girmişti ${ }^{113}$. Bu müsbet ortamdan da yararlanarak; Kastamonu Vali Vekili Ferit Recai Bey, 18 Eylül tarihinde Kaymakamlıklara verdiği emirle Vilayet sınırları içinde hemen Müdafaa-i Hukuk Cemiyetlerinin kurulmasını istemekteydi ${ }^{114}$.

İşte muhtemelen bu emir gereğince Safranbolu Müdafaa-i Hukuk Cemiyeti, Kuva-yı Milliyeci yurtseverlerden Dr. Ali Yaver başkanlığında Kilercioğlu Rıfat, Ayıntapoğlu Mustafa, Eczacı Hidayet, Binbaşioğlu Refik, Değirmencioğlu Mehmet, Avukat Osman, Yüreklioğlu Hasan Fehmi, Gebecioğlu İsmail Bey ve Efendiler'den teşkil etmiştir ${ }^{115}$.

Safranbolu Müdafaa-i Hukuk Cemiyeti de çalı̧̧ma alanımızdaki diğer Müdafaa-i Hukuk Cemiyetleri gibi Milli Mücadele'nin başarıya ulaşması için çaba sarfetmiş̧ir. Ayrıca bu cemiyet, Safranbolu'da

112 ATASE Ata. Özel Arș., Kl: 15, D: 1335/35-3-48, Fh: 8.

$113 \mathrm{Bu}$ konuda daha fazla bilgi için bkz. N. Peker, $1 S V R$, s. 62-86.

114 A.g.e., s. 93.

115 N, Peker, ISVR, s. 94. Safranbolu Müdafaa-i Hukuk Cemiyetinin bu kurucu şahıslarının isimleri Açıksöz gazetesinde de yayınlanmıştır. Bkz. Açıksöz, 2 Mayıs 1336. 
Muin-i Maarif Derneği'ni tesis etmiştir. 23 Ocak 1920 tarihinde 116 Müdafaa-i Hukuk Cemiyeti yönetim kurulu üyesi Eczacı Hidayet Bey Başkanlığında faaliyete geçirilen bu kuruluş̧117. Hüsnü Açıksözcü'nün de belirttiği gibi "fakir ve kimsesiz çocukları okutma işinde iyi ve candan çalışmalar yapmıştı"118. Eğitim ve Öğretim hizmetlerinin yanısıra bu dernek, Bartın İlim ve İrfan Derneği gibi Müdafaa-i Hukuk fikrinin çevrede benimsenmesi ve gelişmesi için de faaliyetlerde bulunmuştur ${ }^{119}$.

\section{F. Yöredeki Diğer Müdafaa-i Hukuk Cemiyetleri}

Buraya kadar anlatılan Müdafaa-i Hukuk Cemiyetlerinden başka Zonguldak ve havalisinde, hakkında fazla bilgi edinemediğịiziz daha birçok milli cemiyetler meydana getirilmiştir.

Bunlardan Çaycuma'da kurulanın başında Tahir Bey vardı. Yöredeki önemli örgütlerden biri olan Amasra Müdafaa-i Hukuk Cemiyeti de Nuri Bey'in çalışmalarıyla kurulmuştur ${ }^{120}$; Hatta Nuri Bey, Osmanlı Hükümeti'ne İstanbul'daki büyük devletlerin elçiliklerine ve İkdam gazetesine “Amasra'nun, Anadolu'nun kopmaz bir parçası olduğunu" açıklayan bir telgraf çekmiştir ${ }^{121}$.

Kurucaşile'de de 2 Mart 1920'de Nişanzade Hüseyin Efendi'nin başkanlığında, Ali ve Nuri Efendiler'den Müdafaa-i Hiukuk Cemiyeti teşkil edildi'122.

Öte yandan Eflani, Ulus ve Alaplı'da da Müdafaa-i Hukuk Cemiyetleri kurulmuştur ${ }^{123}$.

116 Hüsnü Açıksözcü, Safranbolu Muin-i Maarif Derneği'nin 14 Mart 1920 tarihinde kurulduğunu (H. Açıssözcü, a.g.e. s. 79) belirtmektedir. Bu tarih, derneğin kurulduğunu bildiren yazının Aģıssöz'de yayınlanma tarihidir. Bu konuda bkz. Açık Söz 14 Mart 1336

117 Safranbolu Muin-i Maarif Derneği'nin idare heyeti Eczacı Hidayet Bey'den başka şu kişilerden oluşmaktaydı; Alemdarzade Ahmet Burhanettin Efendi, Tüccardan Arabhocazade Kamil Efendi, Hacı kadızade Mehmet Hilmi Efendi, Sepetzade Hüseyin Efendi ve Vali Ömerzade Ömer Salih Efendi'dir (A̧̧ıı Söz, 14 Mart 1336

118 H. Açıksözcü, a.g.e., s. 79. Ayrıca Safranbolu Muin-i Maarif Derneği'nin tamamı 16 madde olan tüzüğü için bkz., $A_{c ̧ ̧ ı k ~} S o ̈ z, 14$ Mart 1336).

119 H. Açıksözcü, a.g.e. s. 81.

120 Turt Ansiklopedisi, C. 10, s. 2780-2781.

121 N. Sakaoğlu, a.g.e., s. 166.

122 ATASE Ata Özel Arş. Kl: 2, D: 1335/3-2, Fh: 110.

123 Alaplı'da 8 Aralık 1919 tarihinden önce kurulmuştur. Zira bu tarihte Mustafa Kemal Paşa Zonguldak, Ereğli ve Alaplı Müdafaa-i Hukuk Cemiyetleri Başkanlıklarına gönderdiği telgrafta; eșkiyalar tarafından dağa kaçırılan bir Italyanın kurtarılması ve asayişin sağlanması için talimat verilmektedir. (ATASE Ata Özel Arş. Kl: 10, D: 1335/24-32, Fh: 54-2). 


\section{SONUÇ}

Zonguldak ve havalisinda müdafaa fikri, Anadolu'nun diğer bölgelerine özellikle -daha önce de örnek olarak gösterildiği gibi- Denizli Sancağı'na göre geç doğmuştur. Bu durumun başlica sebepleri arasında yöre halkının milli hareket lehinde yeterince aydınlatılmamaları gelmektedir. Misal verdiğimiz Denizli Sancağı'nda daha ilk günden itibaren yöneticiler Mustafa Kemal safinda yer alarak halkı bu konuda aydınlatmışlardır. Halbuki çalışma alanımıza giren yörede, aksine mülki idareciler yani mutasarrıf ve kaymakamlar milli hareketi destekleme konusunda ihtiyatlı davranmayı tercih etmişlerdir. Bunların böyle davranmalarının sebeplerinin başında bizce, bulundukları yerde İstanbul Hükümeti'ni temsil etmeleri, dolayısıyla Hürriyet ve İtilaf Fırkası'nın tesirinde kalmış olmaları belirtilebilir.

Yöneticilerin belirtilen tutum ve davranışlarına rağmen, yörede müdafaa fikrinin doğuşu daha fazla gecikmedi. Denizli'de Müftü Ahmet Hulusi Efendi'nin Milli Mücadele için yaptığı önderliği, Zonguldak ve havalisinde de yine din adamları üstlenmişlerdir. Araştırmamız boyunca da açık olarak görüldüğü gibi Müdafaa-i Hukuk Cemiyetlerinin kuruluşu ve gelişmesinde bahsi geçen din adamlarının fevkalâde önemli hizmetleri olmuştur. Bunun yanında, bu cemiyetlerin başarılı olmasında belediye başkanlarının, eşrafin ve askerî şahısların rolü hiç bir zaman küçümsenemez. 


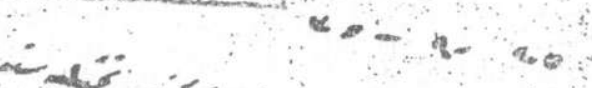

- $\quad-20-20$

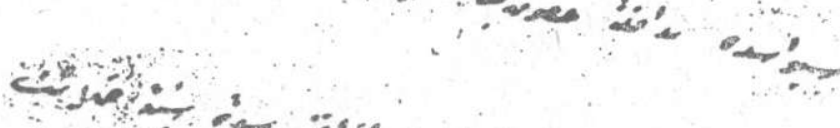

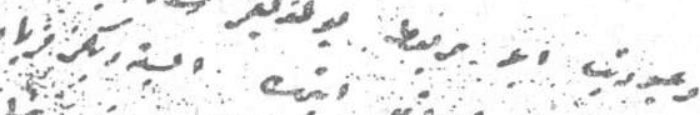

m

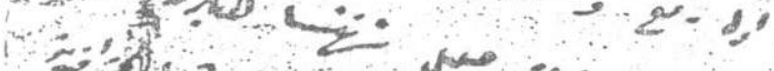

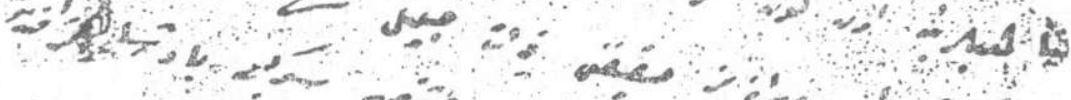
?2:$20 e^{-0}=$ 20

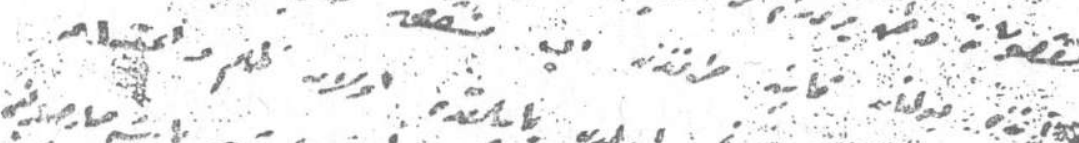
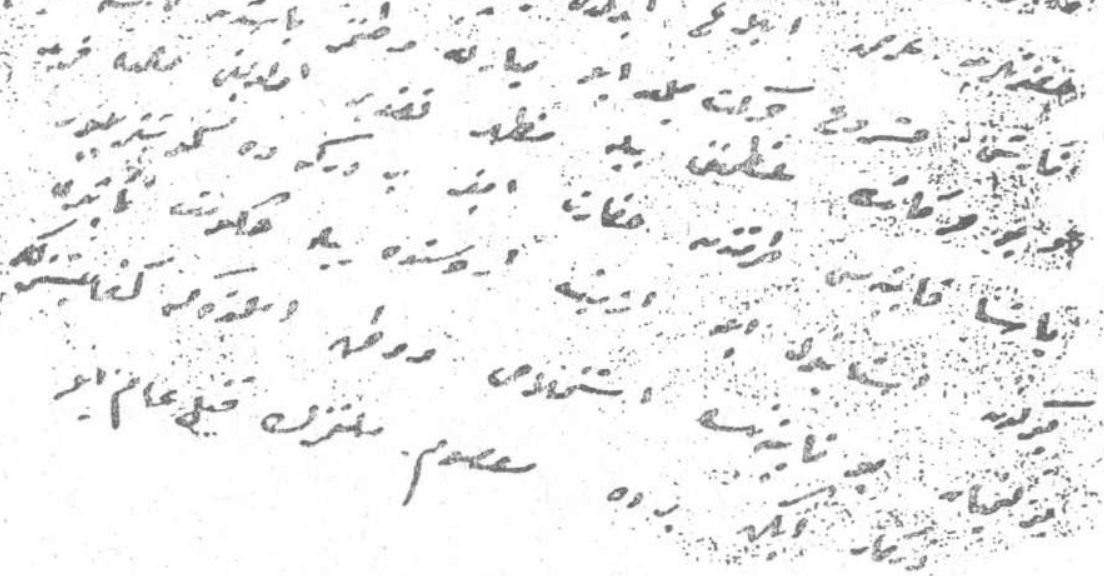

Ek -1. 1/a, 1/b Zonguldak Belediye Başkanı Ibrahim Bey ile Müftü İbrahim Efendi'nin Heyet-i Temsiliye Başkanlı̌̆ı'na gönderdikleri 25.9.1919 tarihli telgraf. Bu telgrafta: Mustafa Kemal Paşa önderliğinde Anadolu da başlatılan hareketin takdir edildiği belirtilerek, ' bu harekete karş̧ı menfi tutum ve davranışlar içerisinde bulunan Damad Ferid Paşa Hükümeti'nin düşürülmesi Heyet-i Temsiliye'den istenmektedir. Bu arada Yunan!ılar'nn insanlık dıșı davranıșları da kınanmaktadır (Cum. Arş. A: III-3, D: 142, Fh: 43, 43-1, $43-2)$. 


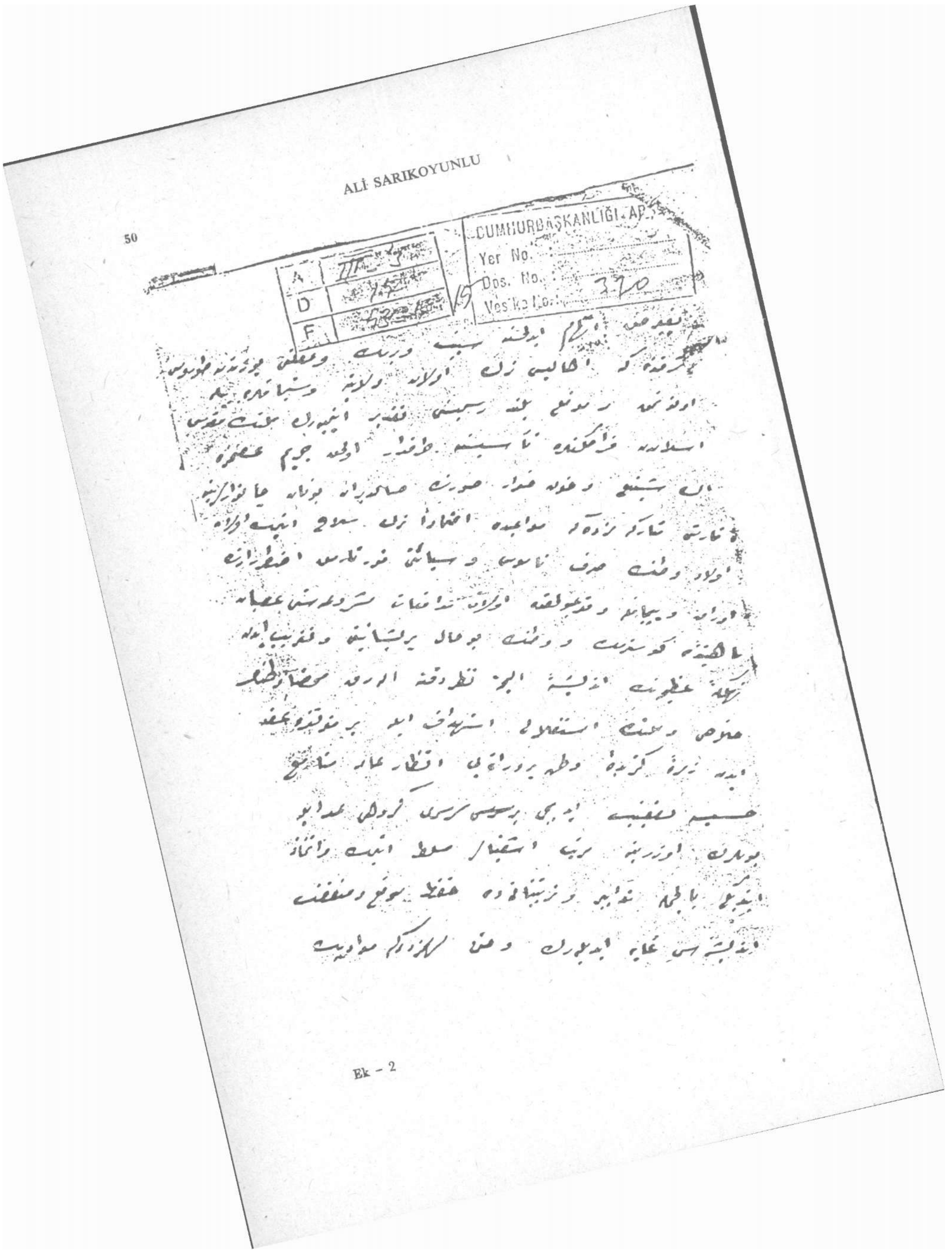




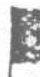
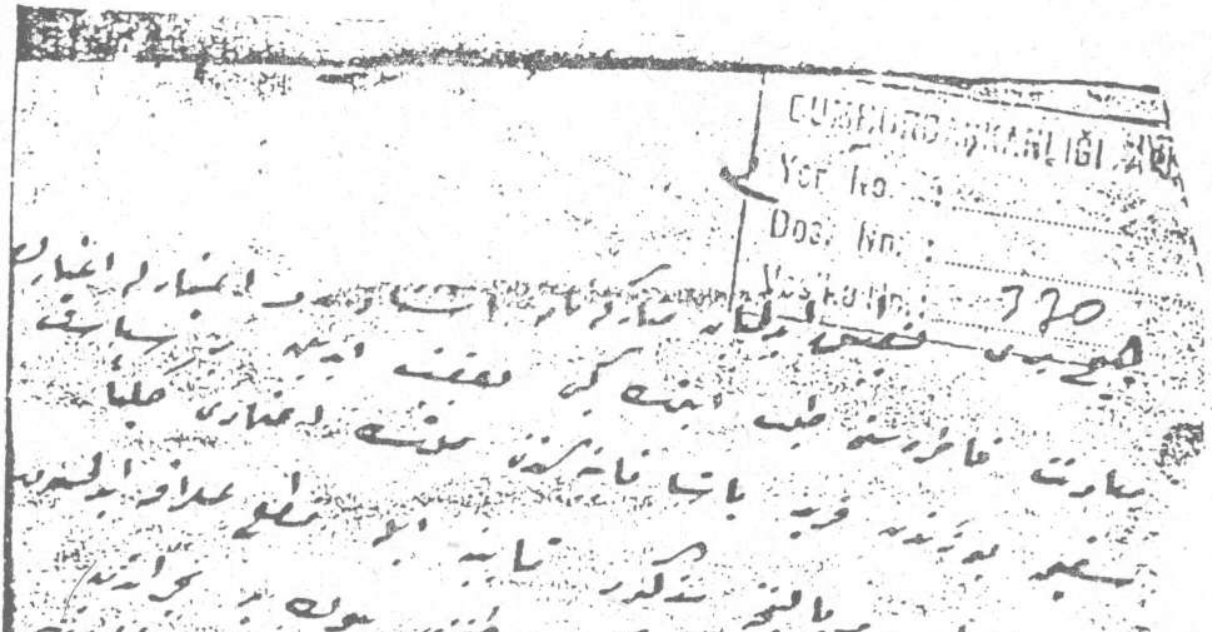

a

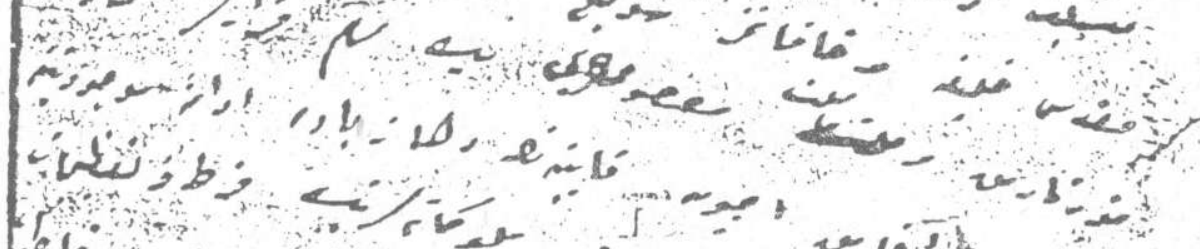

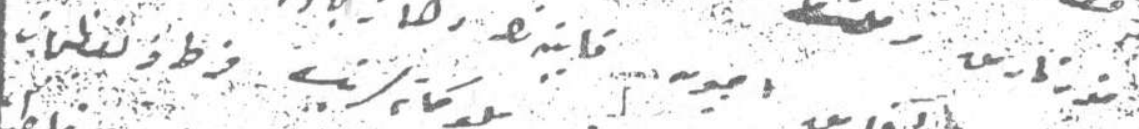

(5)

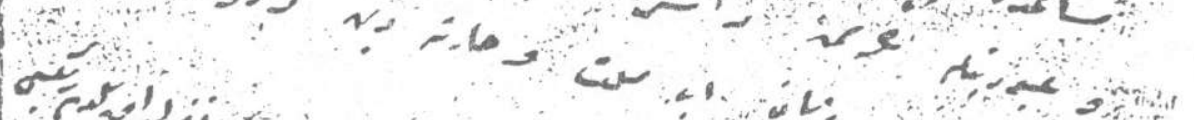

$\mid \int_{-1}^{10}$

Ek - 3 